TAPROBANICA, ISSN 1800-427X. January, 2015. Vol. 07, No. 01: pp. 49-52, pl. 20-21.

(C) Research Center for Climate Change, University of Indonesia, Depok, Indonesia

\& Taprobanica Private Limited, Homagama, Sri Lanka

www.taprobanica.org

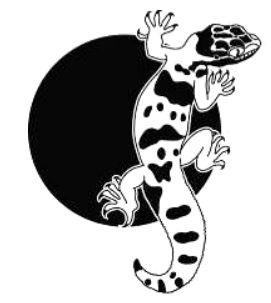

\section{Fish die-off in the Attanagalu-Oya River, Sri Lanka: a provisional checklist of icthyofauna}

Attanagalu Oya basin is situated between the two major river basins Kelani and Maha Oya in Western province of Sri Lanka and has an extent of $779 \mathrm{~km}^{2}$ (Pathirana et al., 2010). It plays a major role in national water supply since it contains four major national water supply and drainage board intakes (NWSDB, 2005). This short communication intends to provide a recent report of fish die-off in the Attanagalu Oya and also include provisional checklist of icthyofaunal diversity in the area. The fish faunal data were collected from the catches of fishermen using cast nets, and hooks. In addition, fish in shallow areas were sampled by using small trawl nets and hand nets. Freshwater fish species were identified and classified by using published field guides (Deraniyagala, 1952; Goonatialke, 2007; Maduranga, 2003; Pethiyagoda, 1991) and recent taxonomic research papers (Batuwita el al., 2013; Meegaskumbura et al., 2008; Ng \& Pethiyagoda, 2013; Pethiyagoda et al., 2008a,b,c; Pethiyagoda et al., 2012; Silva et al., 2008; Silva et al., 2010).

On 2 April 2014 at around $0800 \mathrm{~h}$, in Asgiriya area $\left(7^{\circ} 05^{\prime} 46.84^{\prime \prime} \mathrm{N}, 79^{\circ} 59^{\prime} 03.36^{\prime \prime} \mathrm{E}\right.$, alt. $13 \mathrm{~m}$ a.s.l.) behind the Henarathgoda Botanical Garden, Gampaha (Fig. 1), local community has observed that many fish were coming to the surface of water to breathe air and that the water had turned black. The fish had started to die off in the afternoon $(\sim 1400 \mathrm{~h})$ and continued to do so on the following day as well. Some of the dying fish had been caught by the locals for consumption. According to the locals, more than 1000 individual small and large $(25 \mathrm{~mm}$ to $>1500 \mathrm{~mm}$ ) fish died within these two days. About seven to eight large Wallago attu (Shark Catfish) had been dying and caught by the locals, some exceeding over $1500 \mathrm{~mm}$ in total length. Wallago attu were common until the late 1980s and a popular food fish in both dry and wet zones in Sri Lanka, but currently it is rare and listed as an endangered fish in Sri Lanka (MOE, 2012) due to continuous decline in its area of occupancy.

Authors went to the reported area on 5 April 2014 and found out several dead fish (Appendix I, Fig. 2) as well including a Wallago attu (standard length is $800 \mathrm{~mm}$ ). Interestingly, we have done random fish surveys in the same area during the past few years (2009-2013) and here we provide a provisional checklist of the ichthyofauna in the area and the fish that have died off (Appendix I). We have recorded 47 species (representing 18 families) of fish. Among them, 12 species are endemic to Sri Lanka $(25.5 \%)$ and four species are endangered including Aplocheilus dayi, Pethia nigrofasciata, Pethia reval and Wallago attu. Six exotic species including the highly invasive Pterygoplichthys sp. represented $12.76 \%$ of the total fish recorded. Family Cyprinidae contributed to the majority of fish species $(34.0 \%)$.

The fish die-off could have been due to either natural and human-induced causes (Hohls \& Kuhn, 2001) or a combination of both. Mortality from natural causes is normally the largest single cause of death of individual fish in a population (Hale, 1996). Factors that have been identified in natural fish kills include oxygen depletion, gas super saturation, toxic algal blooms, turnover of the water column, toxic gases, natural toxic substances, sudden or excessive temperature changes, salinity changes, lightning, bacterial infections, fungi, viruses, parasites, and others (Hohls \& Kuhn, 2001). Human-induced factors include discharging of pesticides, fertilizers and other chemicals into water bodies that may act directly on the fish, or indirectly for example, resulting in a sudden decrease in available dissolved oxygen (Hohls \& Kuhn, 2001). Since 
fish were observed gulping air at the surface during the early morning, depletion of dissolved oxygen in the water was likely at least the proximal cause; if so, the ultimate cause was probably excessive discharge of fertilizers and/or organic waste into the water system (Southwick \& Loftus, 2003).

According to the locals, this is the first time such a fish die-off had occurred in the Attangalu Oya. A special investigation had been carried out by the Medical Health Service of the Gampaha district regarding the cause of this fish die-off, however the results are yet to be released (Director, Medical Health Service, Gampaha pers. comm.). The freshwater fish is arguably the most vulnerable taxonomic group as most of the threatened and endemic freshwater species are found outside the protected areas of Sri Lanka (Goonatilake, 2012). Pollution of waterways by urban and industrial refuse, pesticides and agricultural chemicals not only affect the fauna and the environment but the health of people as well (Pethiyagoda, 2006). The water quality of many of the suburban water bodies have undergone drastic changes due to the accumulation of toxic compounds discharged by the industries (Goonatilake, 2012). As such, sound environmental monitoring mechanisms are needed to be implemented to prevent anthropogenic habitat degradation. An example is the Bellanwila-Attidiya sanctuary where the number of freshwater fish had been reduced from 54 to 33 by 2005 (Maduranga, 2005) and 22 species by 2010 (Karunarathna et al. 2010).

According to Pathirana et al. (2010), the COD, $\mathrm{BOD}, \mathrm{DO}, \mathrm{pH}$, nutrient and inorganic ion concentration of Attanagalu Oya are low during the high flow rate due to the dilution effect while values of turbidity and coliform counts are high due to erosion and septic tank over flows. They further emphasize that simple treatment is not adequate for drinking purposes. Thus to ensure both quality of public health and conservation of aquatic fauna in the Attanagalu Oya and surrounding, it's recommended that proper treatment and management of waste should be carried out especially in the urban areas. A proper investigation of a fish die-off should include investigations of many aspects including, such as fisheries management, water quality and chemistry and legal counsel (Southwick \& Loftus, 2003). It's important to document such cases as they could be useful in the future conservation programme.

\section{Literature cited}

Batuwita, S., M. de Silva, and U. Edirisinghe, 2013. A review of the danionine genera Rasboroides and Horadandia (Pisces: Cyprinidae), with description of a new species from Sri Lanka. Ichthyological Exploration of Freshwaters, 24, 121-140.

Deraniyagala, P. E. P., 1952. A coloured atlas of some vertebrates from Ceylon. Volume 1: fishes. National Museum, Colombo: 149.

Goonatilake, S de A., 2007. Freshwater Fishes of Sri Lanka. Ministry of Environment, Colombo, Sri Lanka: 162.

Goonatilake, S. De A., 2012. The Taxonomy and Conservation Status of the Freshwater Fishes in Sri Lanka. Pp. 77-87. In: D. K. Weerakoon and S. Wijesundara (Eds.), The National Red List 2012 of Sri Lanka; Conservation Status of the Fauna and Flora. Ministry of Environment, Colombo, Sri Lanka.

Hale, M., 1996. Fish kill reporting procedure. North Carolina Division of Environmental Management (DEM), Southeastern USA: 92.

Hohls, B. C., and A. L Kühn, 2001. Field Guide to Fish Kill Assessments. Institute for Water Quality Studies, Department of Water Affairs and Forestry, Pretoria, South Africa: 24.

Karunarathna, D.M.S.S., A.A.T. Amarasinghe, D.E. Gabadage, M.M. Bahir, and L.E. Harding 2010. Current status of faunal diversity in Bellanwila-Attidiya Sanctuary, Colombo District, Sri Lanka. Taprobanica, 2: 48-63,

Maduranga, H.G.S., 2003. Endemic Freshwater fish of Sri Lanka (text in Sinhala). Department of National Zoological gardens, Sri Lanka: 122.

Maduranga, H.G.S., 2005. Ichthyofauna of Bellanwila-Attidiya Sanctuary and its environs in Colombo, Sri Lanka. Tigerpaper, 32: 26-32.

Meegaskumbura, M., A. Silva, K. Maduwage, and R. Pethiyagoda, 2008. Puntius reval, a new barb from Sri Lanka (Teleostei; Cyprinidae); Ichthyological Exploration of Freshwaters, 19: 141-152. 
MOE., 2012. The National Red List 2012 of Sri Lanka; Conservation Status of the Fauna and Flora. Ministry of Environment, Colombo, Sri Lanka: 476.

Ng, H. H., and R. Pethiyagoda, 2013. Mystus zeylanicus, a new species of bagrid catfish from Sri Lanka (Teleostei: Bagridae). Ichthyological Exploration of Freshwaters, 24: 161-170.

Pathirana C. D. K., N. J. G. J Bandara, C. Jayaweera, and W. S. C. A Fonseka, 2010. Suitability of Attanagalu Oya as a drinking water resource. Proceedings of the $15^{\text {th }}$ International Forestry and Environment Symposium. University of Sri Jayawardenepura: 26-27.

Pethiyagoda, R., 1991. Freshwater fishes of Sri Lanka. Wildlife Heritage Trust, Colombo, Sri Lanka: 362.

Pethiyagoda, R., 2006. Conservation of Sri Lankan Freshwater Fishes. Pp. 103-112. In: C. N. B. Bambaradeniya, C.N.B. (Ed.), Fauna of Sri Lanka: Status of Taxonomy, Research and Conservation. The World Conservation Union, Colombo, Sri Lanka and Government of Sri Lanka.

Pethiyagoda, R., M. Kottelat, A. Silva, K. Maduwage, and M. Meegaskumbura, 2008a. A review of the genus Laubuca in Sri Lanka, with description of three new species (Teleostei: Cyprinidae). Ichthyological Exploration of Freshwaters, 19: 7-26.

Pethiyagoda, R., A. Silva, and K. Maduwage, 2008b. Mystus ankutta, a new catfish from Sri Lanka (Teleostei: Bagridae). Ichthyological Exploration of Freshwaters, 19: 233-242.

Pethiyagoda, R., A. Silva, K. Maduwage, and M. Meegaskumbura, 2008c. Puntius kelumi, a new species of cyprinid fish from Sri Lanka (Teleostei: Cyprinidae). Ichthyological Exploration of Freshwaters, 19: 201-214.

Pethiyagoda, R., M. Meegaskumbura, and K. Maduwage, 2012. A synopsis of the South Asian fishes referred to Puntius (Pisces: Cyprinidae.). Ichthyological Exploration of Freshwaters, 23: 69-95.

Southwick, R. I., and A. J. Loftus (Eds.), 2003. Investigation and monetary values of fish and freshwater mussel kills. American Fisheries Society, Special Publication 30, Bethesda, Maryland: 177.
NWSDB (National Water Supply \& Drainage board, Sri Lanka), 2005. Low flow study of Attanagalu Oya. National Water Supply and Drainage board, Ratmalana: 45.

Silva A., K. Maduwage, and R. Pethiyagoda, 2008. Puntius kamalika, a new species of barb from Sri Lanka (Teleostei: Cyprinidae). Zootaxa, 1824: 5564.

Silva, A., K. Maduwage, and R. Pethiyagoda, 2010. A review of the genus Rasbora in Sri Lanka, with description of two new species (Teleostei: Cyprinidae). Ichthyological Exploration of Freshwaters, 21: 27-50.

Submitted: 7 May 2014, Accepted: 5 January 2015 Section Editor: Sujan M. Henkanaththegedara

$$
\begin{aligned}
& \text { H. Sudasinghe }{ }^{1} \text {, P. Suranga }{ }^{1} \& \\
& \text { D.M.S.S. Karunarathna } \\
& 1,2
\end{aligned}
$$

\footnotetext{
${ }^{1}$ Young Zoologists' Association of Sri Lanka
} Department of National Zoological Gardens, Dehiwala, Sri Lanka E-mail: hsudasinghe@gmail.com

\footnotetext{
${ }^{2}$ Nature Explorations and Education Team, No. B-1 / G-6, De Soysapura Housing Scheme, Moratuwa 10400, Sri Lanka; E-mail: dmsameera@gmail.com
} 
Appendix I: A provisional checklist of ichthyofauna in the fish die off region of Attanagalu Oya in 2014. (Abbreviations: LC, Least Concerned; NT, Near Threatened; VU, Vulnerable; EN, Endangered; DD, Data Deficient; N, native; E, endemic, I; introduced; * = deaths observed.

\begin{tabular}{|c|c|}
\hline scientific name (common name) & scientific name (common name) \\
\hline Family: Anguillidae & Family: Siluridae \\
\hline Anguilla bicolor ${ }^{\mathbf{L C}, \mathbf{N}}$ (level-finned eel) & *Ompok bimaculatus ${ }^{\mathbf{L C}, \mathbf{N}}$ (butter catfish) \\
\hline *Anguilla nebulosa ${ }^{\mathbf{L C}, \mathbf{N}}$ (long-finned eel) & $*$ Wallago attu ${ }^{\mathbf{E N}, \mathbf{N}}$ (shark catfish) \\
\hline Family:Mastacembelidae & Family: Channidae \\
\hline *Mastacembelus armatus ${ }^{\mathbf{L C}, \mathbf{N}}$ (marbled spiny eel) & $\begin{array}{l}\text { Channa orientalis } \mathbf{v U , \mathbf { E }} \text { (smooth-breasted } \\
\text { snakehead) }\end{array}$ \\
\hline Family: Anabantidae & *Channa punctata ${ }^{\mathbf{L C}, \mathbf{N}}$ (spotted snakehead) \\
\hline *Anabas testudineus ${ }^{\mathbf{L C}, \mathbf{N}}$ (climbing perch) & $*$ Channa striata ${ }^{\mathbf{L C}, \mathbf{N}}($ murrel) \\
\hline Family: Belontidae & Family: Belonidae \\
\hline Belontia signata $^{\mathbf{N T}, \mathbf{E}}$ (Sri Lanka combtail) & $X_{\text {Xenentodon cancila }}^{\mathbf{N T}, \mathbf{N}}$ (freshwater gar fish) \\
\hline $\begin{array}{l}\text { Pseudosphromenus cupanus }{ }^{\mathbf{N T}, \mathbf{N}} \text { (spike-tailed } \\
\text { paradise fish) }\end{array}$ & Family: Aplocheilidae \\
\hline Trichogaster pectoralis ${ }^{\mathbf{I}}$ (snake skin gourami) & Aplocheilus dayi ${ }^{\mathbf{E N}, \mathbf{E}}$ (Sri Lanka Day's killifish) \\
\hline Trichogaster trichopterus ${ }^{\mathbf{I}}$ (three-spot gourami) & Aplocheilus parvus ${ }^{\mathbf{L C}, \mathbf{N}}$ (dwarf panchax) \\
\hline Family: Osphronemidae & Family - Cobitidae \\
\hline Osphronemus goramy ${ }^{\mathbf{I}}$ (giant gourami) & $\begin{array}{l}\text { Lepidocephalichthys thermalis }{ }^{\mathbf{L C}, \mathbf{N}} \text { (common spiny } \\
\text { loach) }\end{array}$ \\
\hline Family:Cichlidae & Family: Cyprinidae \\
\hline *Etroplus suratensis ${ }^{\mathbf{L C}, \mathbf{N}}$ (green chromide) & Amblypharyngodon sp. $^{\mathbf{N}}$ (silver carplet) \\
\hline$*_{\text {Etroplus maculatus }}^{\mathbf{L C}, \mathbf{N}}$ (orange chromide) & $\begin{array}{l}\text { *Dawkinsia singhala }{ }^{\mathbf{L C}, \mathbf{E}} \text { (Sri Lanka filamented } \\
\text { barb) }\end{array}$ \\
\hline Oreochromis mossambicus ${ }^{\mathbf{I}}$ (Mossambic tilapia) & Devario malabaricus ${ }^{\mathbf{L C}, \mathbf{N}}$ (giant danio) \\
\hline Oreochromis niloticus ${ }^{\mathbf{I}}$ (Nile tilapia) & Esomus thermoicos ${ }^{\mathbf{L C}, \mathbf{E}}$ (Sri Lanka flying barb) \\
\hline Family: Gobiidae & Horadandia atukorali $^{\mathbf{V u}, \mathbf{E}}$ (Athukorala's barb) \\
\hline *Awaous melanocephalus ${ }^{\mathbf{L C}, \mathbf{N}}$ (scribbled goby) & $*$ Labeo dussumieri ${ }^{\mathbf{L C}, \mathbf{N}}$ (common labeo) \\
\hline *Glossogobius giuris ${ }^{\mathbf{L C}, \mathbf{N}}$ (bar-eyed goby) & Laubuca sp. ${ }^{\mathbf{E}}$ (flat barb) \\
\hline Family - Bagridae & $\begin{array}{l}\text { Pethia nigrofasciata }{ }^{\mathbf{E N}, \mathbf{E}} \text { (Sri Lanka black ruby } \\
\text { barb) }\end{array}$ \\
\hline Mystus gulio ${ }^{\text {LC, } \mathbf{N}}$ (long-whiskered catfish) & Pethia reval ${ }^{\mathbf{E N}, \mathbf{E}}$ (Sri Lanka red-fined barb) \\
\hline$*_{\text {Mystus vittatus }}^{\mathbf{L C}, \mathbf{N}}$ (striped dwarf catfish) & Puntius bimaculatus ${ }^{\mathbf{L C}, \mathbf{N}}$ (red-side barb) \\
\hline Mystus zeylanicus ${ }^{\mathbf{L C}, \mathbf{E}}$ (Sri Lanka catfish) & *Puntius dorsalis ${ }^{\mathbf{L C}, \mathbf{N}}$ (long-snouted barb) \\
\hline Family: Claridae & *Puntius thermalis ${ }^{\mathbf{L C}, \mathbf{E}}$ (swamp barb) \\
\hline $\begin{array}{l}\text { * Clarias brachysoma }{ }^{\mathbf{N T}, \mathbf{E}} \text { (Sri Lanka walking } \\
\text { catfish) }\end{array}$ & Puntius vittatus ${ }^{\mathbf{L C}, \mathbf{N}}$ (silver barb) \\
\hline Family: Heteropneustidae & Rasbora dandiya ${ }^{\mathbf{L C}, \mathbf{N}}$ (broad-line strip rasbora) \\
\hline *Heteropneustes fossilis ${ }^{\mathbf{L C}, \mathbf{N}}$ (stinging catfish) & Rasbora microcephalus ${ }^{\mathbf{L C}, \mathbf{N}}$ (narrow-line rasbora) \\
\hline Family: Loricariidae & $*$ Systomus cf. sarana ${ }^{\mathbf{D D}}$ (olive barb) \\
\hline \multirow{2}{*}{ Pterygoplichthys sp. (sucker-mouthed catfish) } & Family: Clupeidae \\
\hline & Ehirava fluviatilis $^{\mathbf{N}}$ (Malabar sprat) \\
\hline
\end{tabular}




\section{PLATE 20}
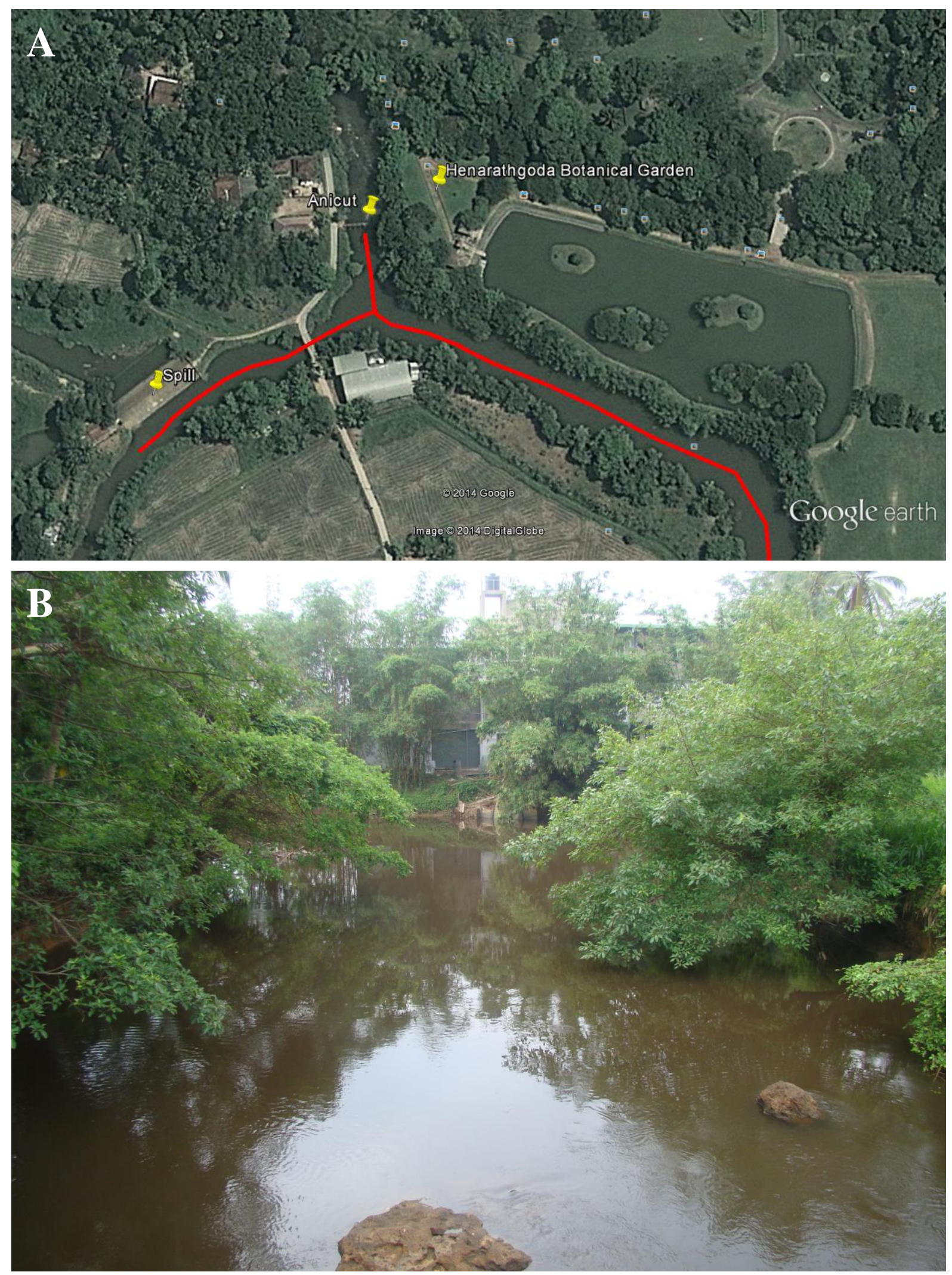

Figure 1: (A) The study area of Attanagalu Oya (region of fish die-off marked by a red line); (B) Habitat of the Attanagalu Oya where the fish die-off observed. 


\section{PLATE 21}
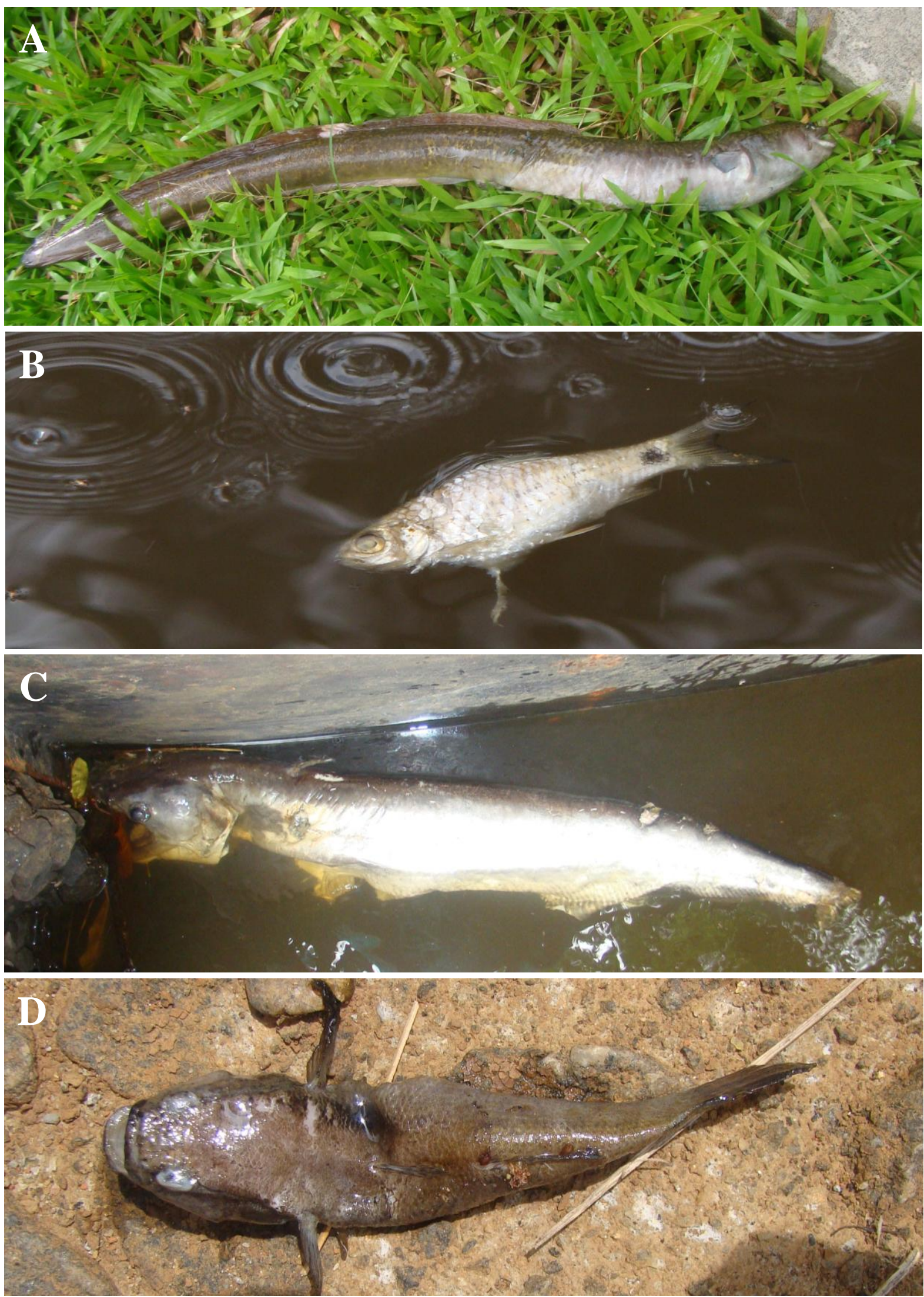

Figure 2: Some of the dead fish observed, A, Anguilla nebulosa (SL 500mm); B, Systomus cf. sarana (SL $\sim 100 \mathrm{~mm})$; C, Wallago attu (SL $\sim 800 \mathrm{~mm})$; D, Channa punctata (SL $\sim 90 \mathrm{~mm})$. 